\title{
An Assessment of Employee Creativity in the Banking Sector of Pakistan
}

\author{
Shabina Shaikh \\ Department of Management Sciences \\ Isra University \\ Email:shabinashaikh@gmail.com \\ DOI: 10.29322/IJSRP.12.01.2022.p12168 \\ http://dx.doi.org/10.29322/IJSRP.12.01.2022.p12168
}

\begin{abstract}
The research paper focuses on assessing and measuring employee creativity of bankers from banking sector of Pakistan. Quantitative data is gathered from commercial banks of Pakistan, 200 bank managers are assessed on employee creativity measuring scale. All respondents are at the managerial level in commercial banks. To assess employee creativity, 13-item measuring scale is adopted, and quantitative data analysis method is applied. Results prove that employee creativity is relatively high at levels of creative performance in banking sector of Pakistan. Results also reveal that creative bankers have innovative skills such as they generate innovative ideas, suggest creative solutions and they plan to implement new ideas.
\end{abstract}

Keywords: Creativity, Employee Creativity, Measuring Employee Creativity

\section{INTRODUCTION}

The term creativity is connected since centuries from geniuses, artists, scientists, and philosophers. Albert Einstein's perspective on creativity reflects wisdom and vision through these famous quotes "Creativity is intelligence having fun" and "Creativity is seeing what everyone else has seen and thinking what no one else has thought". Pablo Picasso was curious about sustaining creativity which is clearly revealed by his quote "Every child is an artist; the problem is staying an artist when you grow up". Vincent van Gogh's perspective shows creativity is achieved by initiating and achieving small tasks, which is reflected in his famous quote "Great things are done by a series of small things brought together".

Many researchers have defined creativity from many different perspectives. The term creativity is applied on person, process, or product. According to Brem et al. (2016) a creative product is the result of either a creative process or a creative person which is considered to be an object. Giampaoli et al. (2017) mentions creativity has gained more attention in literature as it is the most important trait for organizational success.

Starting from the early thoughts on creativity, Stein (1953) states that a novel and useful work is creative work that should be satisfying in some point in time. May (1959) suggests a mindful encounter of humans with the connected objects is creativity. Hence, the early definitions on creativity focus on 'novel', 'usefulness' and 'mindfulness'. Torrance (1969) defines creativity is an ability of finding gaps, coming up solutions to solve problems, producing unique and novel ideas, and having a sense of connecting novel relationship between ideas. Adding further to the definition, Gruteen (1998) states creativity is about divergent thinking and the generation of ideas. A three-dimensional concept says that creativity must have novelty, usefulness and surprise (West et al. 2013), and another dimension of elegance is added to the definition of creativity (Cropley and Cropley 2005) mentions creativity is the ability to apply knowledge to solve problems.

Summarizing all concepts and elements, creativity is defined as the aptitude of coming up novel and unique ideas, identifying gaps, finding solutions, and solving complex problem with elegance and mindfulness.

\section{MEASURING CREATIVITY}

For measuring individual creativity, researchers have given scales and constructs usually based on self-assessed reports. Starting from the early creativity test given by Guilford (1967) names test of divergent thinking which measures creativity focusing on four elements originality, fluency, flexibility, and elaboration. Torrance (1974) presents the extended version divergent thinking named Torrance Thinking Creativity Test (TTCT) and added two more elements in his test, abstractness, and resistance. Khatena (1977) presents another test named Khatena-Torrance Creative Perception Inventory (KTCPI) which measures creativity by measuring artistic inclination, intelligence, individuality, sensitivity, initiative, and self-strength. 
Another test named the adjective check list which carries 30-item scale and measures creativity level (Gough 1979) and then the widely used measuring tested Kirton Adaption-innovation Inventory (KAI) which measures the creative style (Kirton 1976). KAI has 32 items related to creative performance which measure personality dimensions such as ability to adopt, ability to innovate and so on. The summary of all these tests is mentioned in table

Table 1: Tests to Measure Creativity

\begin{tabular}{|l|l|l|l|}
\hline Author & Year & Creativity Test & Measuring Parameters \\
\hline Guilford & 1967 & Guilford's test of divergent thinking & $\begin{array}{l}\text { originality, fluency, flexibility, and } \\
\text { elaboration }\end{array}$ \\
\hline Torrance & $\begin{array}{l}1969, \\
1974\end{array}$ & $\begin{array}{l}\text { Torrance Thinking Creativity Test } \\
\text { (TTCT) }\end{array}$ & $\begin{array}{l}\text { originality, fluency, flexibility, } \\
\text { elaboration, abstractness and resistance }\end{array}$ \\
\hline Kirton & 1976 & $\begin{array}{l}\text { Kirton Adaption-innovation Inventory } \\
\text { (KAI) }\end{array}$ & 32-Item scale \\
\hline Khatena & 1977 & $\begin{array}{l}\text { Khatena-Torrance Creative Perception } \\
\text { Inventory (KTCPI). }\end{array}$ & $\begin{array}{l}\text { artistic inclination, intelligence, } \\
\text { individuality, sensitivity, initiative, and } \\
\text { self-strength. }\end{array}$ \\
\hline Gough & 1979 & $\begin{array}{l}\text { A creative personality scale for the } \\
\text { adjective check list }\end{array}$ & 30-item creative personality scale \\
\hline
\end{tabular}

\subsection{MEASURING EMPLOYEE CREATIVITY}

Research is still providing evidence that tests mentioned in table 1 are valid and still widely in use. Many researchers have developed constructs, measures, and scales to measure employee creativity by considering early tests to measure creativity.

Employee creativity is the creation of useful and new ideas by individual employees (Zhou and George 2001). Creative employees use their voice to exhibit creativity, they propose new ways of doing things and make suggestions on improving things. Thus, creativity is the type of voice behavior and employees perform creatively with the expression of voice (Withey and Cooper 1989).

Everyone is naturally creative; we only need to create is a driving force to enhance creativity in human beings. Creativity is an analytical task (Gurteen 1998); every interaction in our lives is about creativity. The individual and organizational creativity play the driving force to create innovation.

Creativity is initiating new ideas and coming up with new ways of performing things which carries risks because the new ideas may not bring desired positive results (Zhou and George 2001; Withey and Cooper 1989). Literature suggests that useful feedback from colleagues related to handling task increases employees' interest in performing task creatively (Utman 1997). A useful feedback from colleagues increase the employee's perceived effectiveness of creativity; thereby it increases creative activities of employees (Zhou and George 2001).

\subsection{MEASURES OF EMPLOYEE CREATIVITY}

The thirteen-item (Figure 1) measuring the employee creativity is adopted (Sigala \& Chalkiti, 2015) from research paper titled 'Knowledge management, social media and employee creativity'. The findings reveal that the employees reported relatively high levels of creative performance, since the average scores of the eleven out of the thirteen items measuring creativity is higher than the midpoint of the Likert scale (i.e. 3.5).

Sigalaa and Chalkitib (2015) conducted a research to measure employee creativity; their research has 13-item scale. These 13 items are based on the literature that discusses about employee creativity. The literature review in this section also highlights same measures and constructs which develops scale of measuring employee creativity. To measure employee creativity, questionnaire is adopted from research of Sigalaa and Chalkitib (2015). 


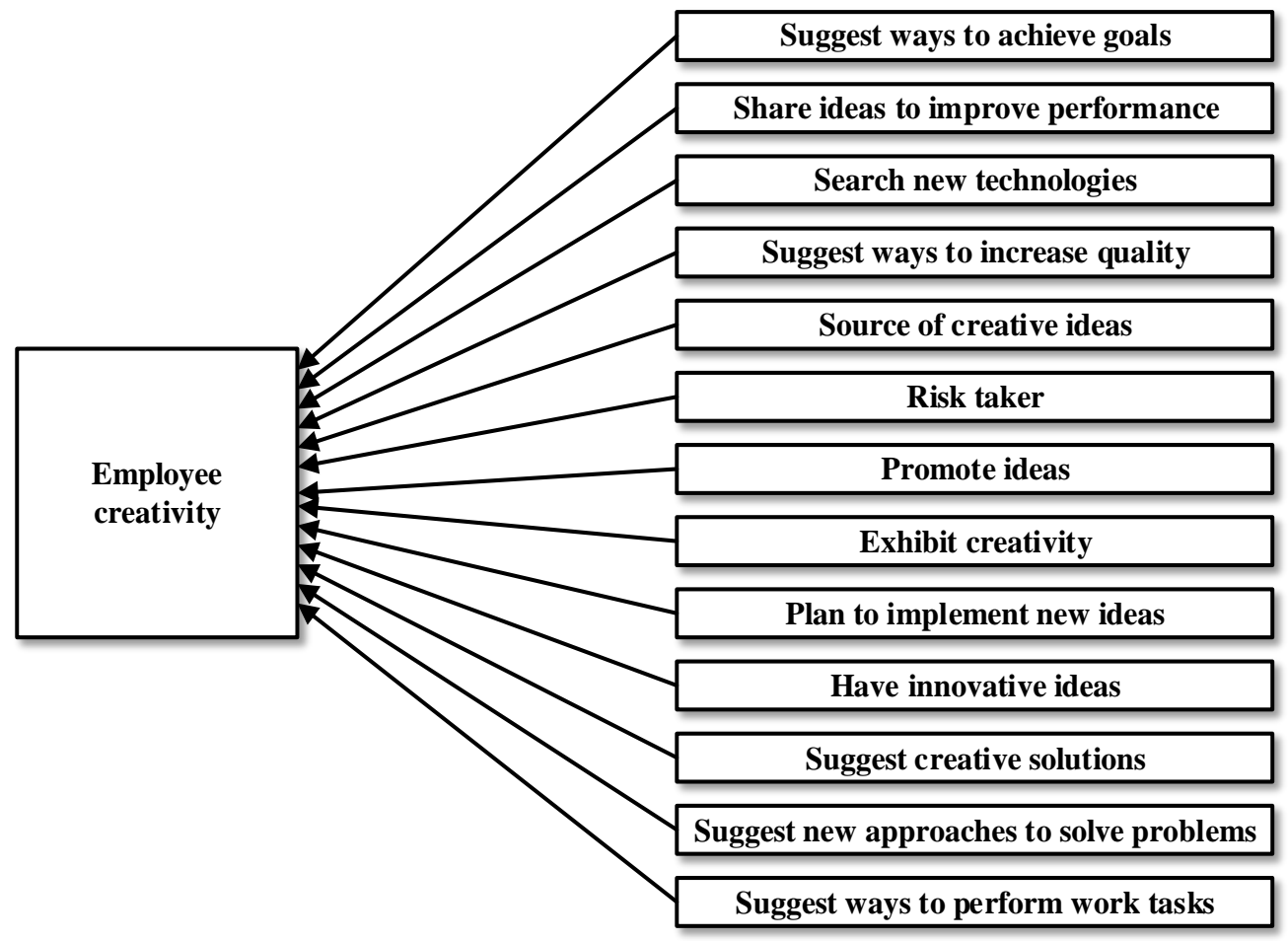

Fig. 1: Measures of Employee Creativity (Sigala \& Chalkiti, 2015)

\subsection{SCALE OF EMPLOYEE CREATIVITY}

Cognitive traits like qualities, personality, perception, and creativity are measured through psychometric techniques which are developed, instituted, and refined in social sciences research (Cook \& Beckman, 2006).

Joshi et al. (2015) highlight two ways through psychometric techniques work; the first technique is using theoretical construct in which measuring instruments are developed and validated, the second way is measuring content items in which scales and models are used.

Psychometric scales like Rasch measurement model are used for estimation of ability, Likert scale measures human attitude, are the examples of scales used widely in the social sciences research. Rating scales in psychometric techniques have several response categories (Sekaran \& Bougie, 2016), Likert scale (Likert, 1932) is one of the rating scales. Likert scale was devised by Rensis Likert to measure 'attitude' in a scientifically accepted and validated manner (Likert, 1932).

Cognitive, affective, and psychomotor all together in various forms constitute delivery of attitude in a specified condition. Likert scale helps to quantify subjective thinking, feeling and action in a validated and reliable manner (Joshi et al., 2015). The Likert scale is a set of statements or items offered for a real or hypothetical situation under study to show the level of agreement (from strongly disagree to strongly agree) with the given statement or item on a metric scale (Likert, 1932). To measure employee creativity, 5 -item Likert scale is used from strongly disagree to strongly agree.

\section{ASSESSING EMPLOYEE CREATIVITY}

To measure the employee creativity 13-item measuring scale is adopted from the Sigala and Chalkiti (2015) research. These items are rated on 5-item Likert scale (Likert, 1932) from strongly disagree to strongly agree. Managers are asked to rate these items on closedended questionnaire. The data is collected from the 200 bankers who are at the managerial level in commercial banks of Pakistan. The label EC (Employee Creativity) represents the creativity measuring item. The mean values and standard deviations are calculated from the entire collected data on 13 measuring items of employee creativity (Table 2). The highest mean value is 3.97, deviated from standard 0.70 , on the item 'have innovative ideas' which means majority of bankers do have the ability to think innovatively. The lowest mean value is 2.66 , deviated from standard 0.89 , on the item 'risk taker' which means bankers prefer working on tasks where risk is not involved, and outcomes are already predicted. 
Table 2: Descriptive Statistics of Employee Creativity

\begin{tabular}{|l|l|l|l|}
\hline Label & Name & Mean & Std. Deviation \\
\hline EC1 & Suggest ways to achieve goals & 3.73 & 0.93 \\
\hline EC2 & Ideas to improve performance & 3.75 & 0.86 \\
\hline EC3 & Search new technologies & 3.30 & 0.83 \\
\hline EC4 & Suggest ways to increase quality & 3.78 & 0.83 \\
\hline EC5 & Source of creative ideas & 3.17 & 0.79 \\
\hline EC6 & Risk taker & 2.66 & 0.89 \\
\hline EC7 & Promote ideas & 3.72 & 0.78 \\
\hline EC8 & Exhibit creativity & 3.21 & 0.92 \\
\hline EC9 & Plan to implement new ideas & 3.83 & 0.74 \\
\hline EC10 & Have innovative ideas & 3.97 & 0.70 \\
\hline EC11 & Suggest creative solutions & 3.88 & 0.75 \\
\hline EC12 & New approach to problems & 3.07 & 0.86 \\
\hline EC13 & Suggest ways to perform work tasks & 3.78 & 0.82 \\
\hline
\end{tabular}

The findings (Figure 2) reveal that the first item of employee creativity is near on the point 4 which means majority of managers in banking sector suggest ways to achieve goals. The second item of employee creativity is also near to point 4 which means managers in banking sector do come up and share ideas to improve performance. The third item of employee creativity is near to point 3 which means majority of manager are not familiar with searching of new technologies. The fourth item of employee creativity is near to point 4 which means managers do suggest ways to improve quality at workplace. The fifth item of employee creativity is near to point 3 which means majority of managers are not familiar with the sources of creative ideas. The sixth item of employee creativity is between point 2 and 3 which means majority of bankers do avoid taking risk. The seventh item of employee creativity is near to point 4 which means manager encourage new ideas. The eighth item of employee creativity is near to point 3 which means managers are not sure if they exhibit creativity or not. The ninth item of employee creativity is near to point 4 which means manager do plan to implement new ideas in banks. The tenth item of employee creativity is near to point 4 which means majority of managers do have innovative ideas to share at workplace. The eleventh item of employee creativity is near to point 4 which means managers suggest creative solutions in banks. The twelfth item of employee creativity is near to point 3 which means managers are not sure about the new approaches and methods to the problems. The last thirteenth item of employee creativity is near to the point 4 which means majority of managers do suggests ways to perform tasks in the banks. Overall, the employee creativity is relatively high at levels of creative performance, since the average score of the thirteen items measuring creativity is 3.81 which is higher than the mid-point of the Likert scale (i.e. 3.5). 


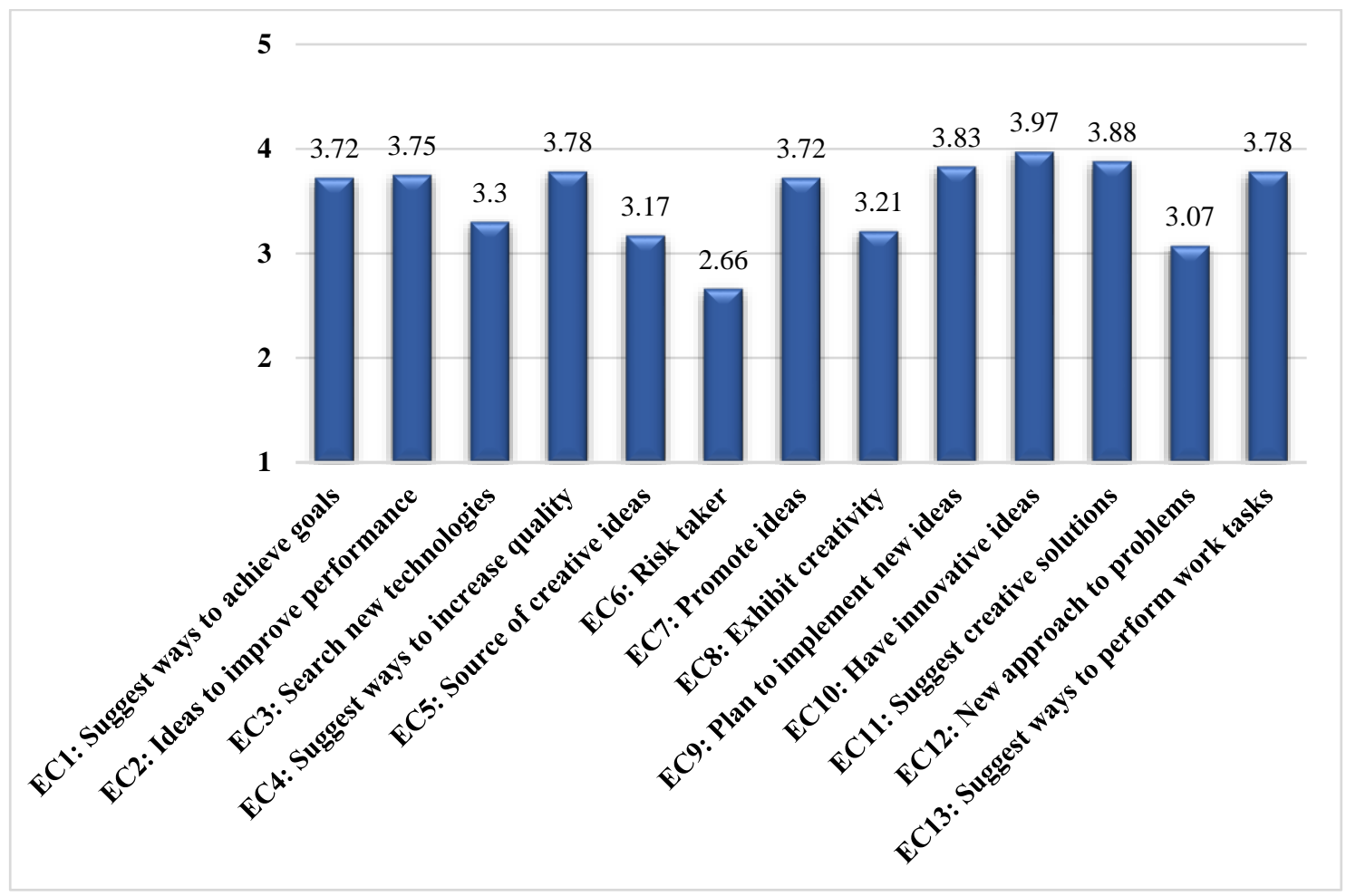

Fig. 2: Employee Creativity on 5 Point Scale

\subsection{RELIABILITY STATISTICS OF EMPLOYEE CREATIVITY MEASURES}

The reliability of measure is calculated to know if the measure indicates stability and consistency with which the instrument measures the concept and helps to assess the goodness of a measure (Sekaran and Bougie, 2016). There are many ways through which reliability of items are tested. For the variable employee creativity, inter-item consistency reliability is tested through SPSS. The inter-item consistency tests find out the consistency of respondents' answers to all the items in a measure. The most popular test of inter-item consistency reliability is the Cronbach's coefficient alpha (Cronbach, 1946) which is used for multipoint-scaled items. According to Cronbach the higher the coefficients the better measuring instrument. To calculate Cronbach's alpha, SPSS is used (Table 3). The value of coefficient of Cronbach's Alpha of employee creativity measure is 0.796 which is approximate $79 \%$ and suggests the measuring items are consistent.

Table 3: Reliability Statistics of Employee Creativity

\begin{tabular}{|l|l|}
\hline Cronbach's Alpha & N of Items \\
\hline 795 & 13 \\
\hline
\end{tabular}

\section{CONCLUSION}

The aim of this research is to measure the employee creativity of bankers. The thirteen items of measuring employee creativity are measured on 5-point Likert scale. This concludes that the employee creativity in bankers is relatively high at scale of employee creativity, since the average score of the thirteen items measuring creativity is 3.81 which is higher than the mid-point of the Likert scale (i.e. 3.5). Overall, results conclude that creative bankers do have innovative ideas but they are less likely to take risk. 


\section{REFERENCES}

Brem, A., Puente-Diaz, R., \& Agogué, M. (2016). Creativity and innovation: State of the art and future perspectives for research. International Journal of Innovation Management, 20(04), 1602001. https://doi.org/10.1142/S1363919616020011

Cook, D. A., \& Beckman, T. J. (2006). Current concepts in validity and reliability for psychometric instruments: theory and application. The American journal of medicine, 119(2), 166-e7. https://doi.org/10.1016/j.amjmed.2005.10.036

Cropley, D. H., \& Cropley, A. J. (2005). Engineering creativity: A systems concept of functional creativity. Creativity across domains: Faces of the muse, 1(15), 169-185.

Cronbach, L. J. (1946). Response sets and test validity. Educational and psychological measurement, 6(4), 475-494. https://doi.org/10.1177/001316444600600405

Gough, H. G. (1979). A creative personality scale for the adjective check list. Journal of personality and social psychology, 37(8), 1398. https://doi.org/10.1037/0022-3514.37.8.1398

Guilford, J. P. (1967). The nature of human intelligence. McGraw-Hill.

Giampaoli, D., Ciambotti, M., \& Bontis, N. (2017). Knowledge management, problem solving and performance in top Italian firms. Journal of Knowledge Management, Vol. 21 No. 2, pp. 355-375. https://doi.org/10.1108/JKM-03-2016-0113

Gurteen, D. (1998). Knowledge, creativity and innovation. Journal of knowledge Management, 2(1), 5-13.

Joshi, A., Kale, S., Chandel, S., \& Pal, D. K. (2015). Likert scale: Explored and explained. Current Journal of Applied Science and Technology, 396-403. https://doi.org/10.9734/BJAST/2015/14975

Khatena, J. (1977). The Khatena-Torrance Creative Perception Inventory for identification diagnosis facilitation and research. Gifted Child Quarterly, 21(4), 517-525. https://doi.org/10.1177/001698627702100410

Kirton, M. (1976). Adaptors and innovators: A description and measure. Journal of applied psychology,61(5), 622. https://doi.org/10.1037/0021-9010.61.5.622

Likert, R. (1932). A technique for the measurement of attitudes. Archives of psychology. 22 140, 55.

May, R. (1959). The nature of creativity. ETC: A Review of General Semantics, 261-276.

Sigala, M., \& Chalkiti, K. (2015). Knowledge management, social media and employee creativity. International Journal of Hospitality Management, 45, 44-58. https://doi.org/10.1016/j.ijhm.2014.11.003

Sekaran, U., \& Bougie, R. (2016). Research methods for business: A skill building approach. John Wiley \& Sons. ISBN: 978-1-11916555-2.

Stein, M. I. (1953). Creativity and culture. The journal of psychology, 36(2), 311-322. https://doi.org/10.1080/00223980.1953.9712897

Torrance, E. P. (1969). Creativity. What Research Says to the Teacher, Series, No. 28.

Torrance, E. P. (1974). The Torrance Tests of Creative Thinking: Norms-Technical Manual. Princeton, NJ: Personal Press.

Utman, C. H. (1997). Performance effects of motivational state: A meta-analysis. Personality and Social Psychology Review, 1(2), 170182. https://doi.org/10.1207/s15327957pspr0102_4

Withey, M. J., \& Cooper, W. H. (1989). Predicting exit, voice, loyalty, and neglect. Administrative science quarterly, 521-539. https://doi.org/10.2307/2393565

West, D., Caruana, A., \& Leelapanyalert, K. (2013). What Makes Win, Place, or Show?: Judging Creativity in Advertising at Award Shows. Journal of Advertising Research, 53(3), 324-338. https://doi.org/10.2501/JAR-53-3-324-338

Zhou, J., \& George, J. M. (2001). When job dissatisfaction leads to creativity: Encouraging the expression of voice. Academy of Management journal, 44(4), 682-696. https://doi.org/10.5465/3069410 